\title{
TIFL Games in the Arab world: How the Baby Olympics is used as a pathway for sport promotion and Olympic education?
}

\author{
LEONARDO JOSE MATARUNA-DOS-SANTOS1,2,3 $\triangle$, MOHAMMED SAYEED KHAN ${ }^{3}$, MOHAMED AHMED \\ HAAMED MAHMOUD SAYED AHMED ABDELWAHAB AL-SHIBINII ${ }^{4}$, SARA AL-KATHEERI ${ }^{4}$, AMNA MOHAMAD ALI ${ }^{4}$, \\ DANIEL RANGE², ASLI CAZORLA MILLA ${ }^{5,3}$ \\ ${ }^{1}$ Sport Management Department, Faculty of Management, Canadian University of Dubai, Dubai, United Arab Emirates \\ ${ }^{2}$ Centre for Trust, Peace and Social Relation, Coventry University, Coventry, United Kingdom \\ ${ }^{3}$ Faculty of Arts, Federal University of Rio de Janeiro, Rio de Janeiro, Brazil \\ ${ }^{4}$ College of Business Administration, American University in the Emirates, Dubai, United Arab Emirates \\ ${ }^{5}$ Management, Marketing and Logistics Department, College of Business Administration, American University in the Emirates, \\ Dubai, United Arab Emirates
}

\begin{abstract}
In the Middle East and North African (MENA) region, the Arabic term 'tif' is used to refer to both baby and child. The aim of this research study was to understand the motives of the National Olympic Committees (NOCs) of the MENA region to invest, organise and promote the 'Tifl Games', also known as 'Baby Olympics'. The toddlers compete for the ultimate prize in various sport events which try to embody the core Olympic values of excellence, respect and friendship. The situational analysis methodology based on qualitative data after the digital review of the events was utilised for the study. The NOCs of the MENA region were observed through the official websites, social media channels (YouTube, Facebook, Instagram, Linkedln, and Twitter), news and digital reports. The results show that the opportunity to develop consumer engagement and future talent identification are the main reasons for the organisation of the events. The existence of misconceptions in the MENA region regarding the practise of sports by toddlers was also highlighted in this study. The lack of elite athletes or high-performance sports programmes opened a new door to promote the message of Olympism for the youth generation. The conclusions alert that it is necessary to avoid the precocious training or competition in early age stages. Unconventional training regimes coupled with the inhumane treatment the young athletes are subjected to shed light on the great lengths some countries are willing to go to claim supremacy in the sporting arena. The 'Tifl Games' are an excellent opportunity for sport participation, sport promotion and Olympic education in a region with a deficit of sport for development though care should be taken by the NOCs to protect the human rights, adhere to the child protection policy and avoid exploitation of the young athletes.
\end{abstract}

Keywords: Baby Olympics; MENA region; Youth sports.

Cite this article as:

Mataruna-Dos-Santos, L.J., Khan, M.S., Al-Shibini, M.A.H.M.S.A.A., Al-Katheeri, S., Ali, A.M., Range, D., \& Milla, A.C. (2021). TIFL Games in the Arab world: How the Baby Olympics is used as a pathway for sport promotion and Olympic education? Journal of Human Sport and Exercise, 16(1proc), S14-S22. doi:https://doi.org/10.14198/jhse.2021.16.Proc1.02

Corresponding author. Canadian University of Dubai - Faculty of Management - Sport Management Department - City Walk Campus - Dubai, United Arab Emirates. https://orcid.org/0000-0001-9456-5974

E-mail: leonardo.mataruna@cud.ac.ae

Supplementary Issue: Rio 2016 Olympic Games Fourth Anniversary Special Edition. Olympic Studies Forum, 21-24 October 2020. Olympic Studies Research Group, Pontifical Catholic University of Rio Grande do Sul (GPEO PUCRS), Brazil.

JOURNAL OF HUMAN SPORT \& EXERCISE ISSN 1988-5202

(C) Faculty of Education. University of Alicante

doi:10.14198/jhse.2021.16.Proc1.02

S14 | 2021| Proc1 | VOLUME 16

C 2021 University of Alicante 


\section{INTRODUCTION}

The International Olympic Committee (IOC) and the International Paralympic Committee (IPC) are utilising various strategies to promote gender equality and participation for all irrespective of their age in the mega sport events; be it in the form of competing, watching or volunteering in the ever-growing and evolving sports industry (Mataruna et.al, 2018).

A decade ago, the IOC launched the Youth Olympic Games (YOG) with a vision to encourage the youth population to participate in sports, inculcate the Olympic values of excellence, friendship and respect and promote the adoption of Olympism in their daily life. The YOG were created to spread awareness among the youth regarding the importance of participation in sports and celebrate unity in diversity existing in different cultures (International Olympic Committee, 2015).

The development of the concept of 'Baby Olympics' by the National Olympic Committees (NOC) of the Middle East and North African (MENA) region exemplifies their efforts to promote the participation of youth athletes from grassroots level. The MENA region is economically active in the world and has favourable conditions for investments in sports and other sectors due to the presence of rich fossil fuel reserves such as oil, petroleum and natural gas. It is composed of countries namely: Algeria, Bahrain, Djibouti, Egypt, Iran, Iraq, Jordan, Kuwait, Lebanon, Libya, Morocco, Oman, Qatar, Saudi Arabia, Syria, Tunisia, West Bank and Gaza, Yemen and the United Arab Emirates. Ethiopia and Sudan are sometimes included in the MENA (The World Bank Group).

The reality paints a different picture; few countries in the MENA region take advantage of the investment opportunities available in the sports industry. The local sports scene is dominated by two sports namely, football and equestrian. Rest of the sports are often side-lined and looked over in terms of development but the NOCs have warned the local sports governing authorities and set stringent guidelines regarding talent identification and sports participation for all. The MENA countries should follow the IOC blueprint towards a more physically active and healthy society by promoting the participation of teenagers in mega sporting events such as the YOG (Souza et.al, 2019). Sports plays a pivotal role in a few countries of the MENA region. Nonetheless, the member states of the Gulf Cooperation Council (GCC) - Bahrain - or Kingdom of Bahrain, Kuwait, Oman - or Sultanate of Oman, Qatar, Saudi Arabia - or Kingdom of Saudi Arabia (KSA), and the United Arab Emirates (UAE) - have hardly invested in the last decade to enhance the local and global identity of the countries.

In order to promote the Olympic Games and increase consumer engagement, IOC developed marketing campaigns through social media as depicted in Figures 1 (A) and (B). There are not a proper competition, but a strategic campaign to attract people through 'cute' videos. IOC promoted the concept of Baby Olympics and the participation of toddlers in a competitive sport setting on their official YouTube channel. The aim of the IOC through those videos is to normalise the idea of integration of potential athletes starting from the early stages of childhood and to show that it can be carried out in a one-of-a-kind fun, positive and entertaining setting. The NOC's of the MENA region should utilise their digital media channels effectively to encourage the youth to indulge in any form of exercise or physical activity (Mataruna et.al, 2019).

The organisation of the Baby Olympics could prove to be a boon for the IOC and the image of Olympic Games worldwide with the Olympic Games possibly overtaking the FIFA World Cup as the biggest sporting event in the world (Pumerantz, 2012). Sportsmanship spirit developed due to early exposure to a competitive sporting environment could help the young athletes to absorb losses, stay motivated and away from negative 
influences in the later stages of life. A special bond may be developed between the parent and child due to involvement of parents from an early stage in an athlete's career further motivating the athlete to achieve excellence in the sporting arena.
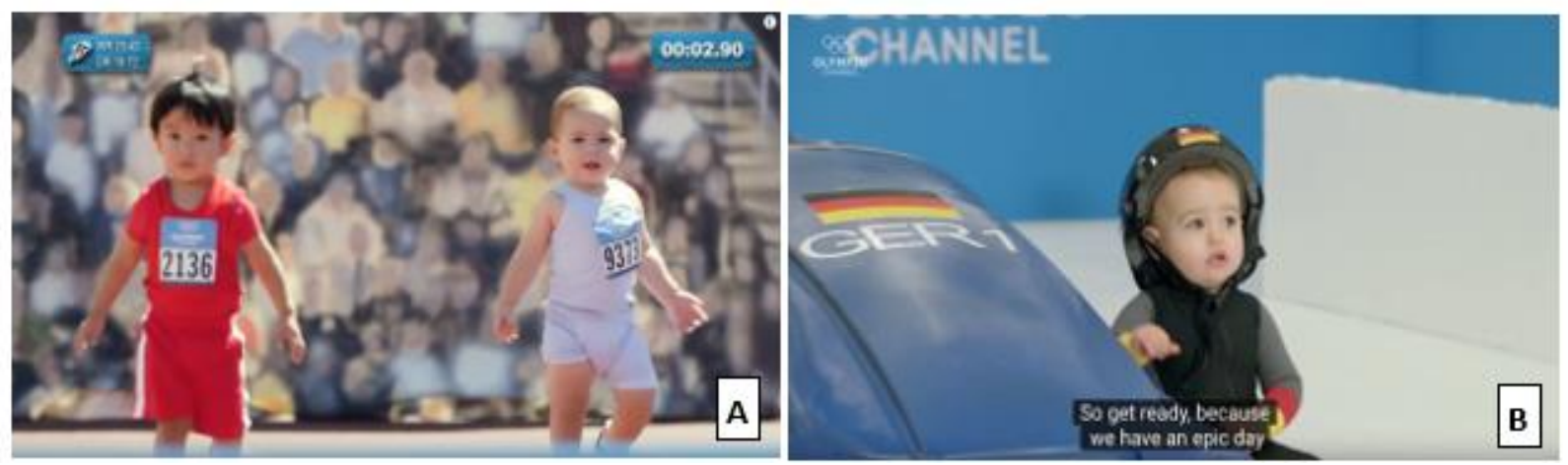

Source: (A) Olympic Channel (2017); (B) Olympic Channel (2018).

Figure 1. (A) IOC promoting the Olympic Games, using the Baby Olympics concept, (B) IOC promoting the Winter Games using the Baby Olympics concept.

Earlier, the Olympic Games could only be consumed through the medium of radio or television sets (Sopko, 2018). The digital age has transformed the broadcasting landscape by providing consumers with unprecedented access to the Olympic spectacle through an array of platforms such as over-the-top (OTT) streaming services and social media (Hutchins \& Mikosza, 2010). The multiple channels allow the IOC to create and distribute various types of content leading to increased engagement with spectators (Mataruna et.al, 2015).The expanding userbase of internet can translate into increased viewership and higher ratings of the Olympic Games for the governing body (Marshall et.al, 2010). Some events for baby, toddlers and kids became recurrent in the MENA region with the competition format facing the early ages.

The objective of this research study was to explain the concept of 'Tifl Games' and explore through business analysis, the motive behind hosting various baby-centric sporting events and the values incorporated worldwide with a special focus on the MENA region under the respective NOCs.

\section{MATERIALS AND METHODOLOGY}

The data and information related to Baby Olympics in the MENA region was collected from various digital sources such as the official websites of the NOC's and their corresponding digital media platforms (Facebook, Instagram, Linkedln, Twitter and YouTube).

STEEPLE Analysis was utilised to formulate the factors affecting the Baby Olympics in the MENA region (Wozniak, 2019). The concept of Baby Olympics in other parts of the world was also studied through digital sources such as newspaper reports to understand the overall scenario.

\section{RESULTS AND DISCUSSION}

The economies of the developing countries heavily rely on the young working-class population. An active and fit society can go a long way in determining a nation's growth and its position among the global economies. Embedding the principles and values associated with sport at an early stage of childhood can 
enhance the development of the citizens which eventually will be reflected in the growth of a country. The MENA countries are adopting various strategies to boost their economic growth and improve the standard of living; Baby Olympics is one of the tools utilised to realise the ultimate goal.

UAE was the first country in the MENA region to host the Baby Olympics in the year 2003. Babies and toddlers in the age group of 3 months - 36 months competed in various events such as crawling contest, walker contest and tricycle contest (Khaleej Times, 2004). Kingdom of Saudi Arabia hosted its first Baby Olympics in 2017 in the city of Jeddah (General Authority for Entertainment, 2017). 2019 Bahrain Baby Games received tremendous response with over 1,029 participants competing in the four-day event (Bahrain News Agency, 2019). Positive reception from the consumers in the MENA region will drive the NOC's motivation to increase the number of event offerings in the future. An excerpt from the interview of a key stakeholder involved in the organisation of the Baby Olympics in the Kingdom of Saudi Arabia (KSA) (Al Arabiya, 2017):

"We conceptualised the idea of organising the first ever Baby Olympics in the Kingdom of Saudi Arabia. Globally, it is held regularly with events such as the crawl race so we added the family relay race event to raise awareness in the society and strengthen the bond between a parent and child."

Table 1. STEEPLE analysis of Baby Olympics.

\begin{tabular}{|c|c|c|c|c|c|c|}
\hline Sociological & Technological & Economic & Ecological & Political & Legal & Ethical \\
\hline $\begin{array}{l}\text { Existing } \\
\text { misconceptions } \\
\text { on babies } \\
\text { practicing sports } \\
\text { in MENA region. }\end{array}$ & $\begin{array}{l}\text { Exposure of } \\
\text { babies to } \\
\text { radiating } \\
\text { screens poses } \\
\text { health risks. }\end{array}$ & $\begin{array}{l}\text { Exorbitant } \\
\text { fees charged } \\
\text { by training } \\
\text { academies. }\end{array}$ & $\begin{array}{l}\text { A platform for } \\
\text { babies to } \\
\text { nurture their } \\
\text { skillset. }\end{array}$ & $\begin{array}{l}\text { Incentives to } \\
\text { create } \\
\text { awareness } \\
\text { and } \\
\text { encourage } \\
\text { the families } \\
\text { to allow } \\
\text { babies to } \\
\text { practise } \\
\text { sports. }\end{array}$ & $\begin{array}{l}\text { No } \\
\text { constitutional } \\
\text { framework } \\
\text { preventing } \\
\text { the misuse of } \\
\text { babies. }\end{array}$ & $\begin{array}{l}\text { Utilisation of } \\
\text { babies as a } \\
\text { marketing tool. }\end{array}$ \\
\hline $\begin{array}{l}\text { Overprotective } \\
\text { parents present } \\
\text { cultural barriers. }\end{array}$ & $\begin{array}{l}\text { A testing } \\
\text { ground for the } \\
\text { development of } \\
\text { Artificial } \\
\text { Intelligence } \\
\text { powered } \\
\text { devices to } \\
\text { improve the } \\
\text { quality of life of } \\
\text { a baby. }\end{array}$ & $\begin{array}{l}\text { Cash prizes } \\
\text { for } \\
\text { economically } \\
\text { vulnerable } \\
\text { families. }\end{array}$ & $\begin{array}{l}\text { Hygiene } \\
\text { issues with } \\
\text { handling of } \\
\text { babies. }\end{array}$ & $\begin{array}{l}\text { Formulation } \\
\text { of policies } \\
\text { regarding } \\
\text { the practise } \\
\text { of sports } \\
\text { and physical } \\
\text { activity by } \\
\text { babies. }\end{array}$ & $\begin{array}{l}\text { Parents to be } \\
\text { held } \\
\text { accountable } \\
\text { in case of any } \\
\text { mishap. }\end{array}$ & $\begin{array}{l}\text { Overtraining } \\
\text { poses health } \\
\text { risks. }\end{array}$ \\
\hline $\begin{array}{l}\text { A good space to } \\
\text { unify families } \\
\text { from different } \\
\text { backgrounds. }\end{array}$ & $\begin{array}{l}\text { Early } \\
\text { integration of } \\
\text { technological } \\
\text { devices will } \\
\text { lead to 'smart } \\
\text { babies'. }\end{array}$ & $\begin{array}{l}\text { A good } \\
\text { opportunity } \\
\text { for } \\
\text { organisations } \\
\text { catering to } \\
\text { babies to } \\
\text { utilise the } \\
\text { event as a } \\
\text { marketing } \\
\text { opportunity. }\end{array}$ & $\begin{array}{l}\text { Excellent } \\
\text { platform for } \\
\text { promoting } \\
\text { health and } \\
\text { education } \\
\text { initiatives } \\
\text { such as child } \\
\text { vaccinations. }\end{array}$ & $\begin{array}{l}\text { Geopolitical } \\
\text { tensions } \\
\text { existing } \\
\text { among the } \\
\text { MENA } \\
\text { countries. }\end{array}$ & $\begin{array}{l}\text { Prior medical } \\
\text { examination } \\
\text { by a certified } \\
\text { paediatrician } \\
\text { to clear the } \\
\text { baby to } \\
\text { compete in } \\
\text { the events is } \\
\text { not } \\
\text { mandatory. }\end{array}$ & $\begin{array}{l}\text { Confidentiality } \\
\text { issues related } \\
\text { to identities of } \\
\text { parents and } \\
\text { babies. }\end{array}$ \\
\hline
\end{tabular}

Source: Developed by the authors. 
The Egyptian Minister of Youth and Sports, Mr Ashraf Sobhy, shared a blueprint for the organisation of the Baby Olympics in his country (Al Ahly Tv, 2019). The participants of the Egyptian Baby Olympics will have to undergo preliminary qualification rounds which will be held in youth centres or sporting clubs spread across the nation. The athletes will compete in events classified according to their respective age groups. Scouts will be present to spot talented athletes and draft them into the national team setup. He has stated on record that the governing body of Egypt has a vision to stage events centred around children consistently over the years to come with the Baby Olympics acting as a starting point. He requested the media outlets to cover the event and promote it for maximum reach among the masses which will prove to be beneficial for the children of the nation. The external factors that impact the promotion of Baby Olympics can be find in the STEEPLE analysis (see Table 1).

"Westernization" of sport in the MENA region is heavily influenced by the various international media outlets such as social media and television which, in turn, could act as a catalyst and lead to the adoption of American or European culture and practices (see the examples from other countries at the Figure 2).

YouTube content creators have hopped on the bandwagon by producing content on the topic of Baby Olympics, although with no affiliations to the governing bodies. A simple YouTube search yields results such as 'Minecraft - Baby Olympics' (Mangotango, 2016).
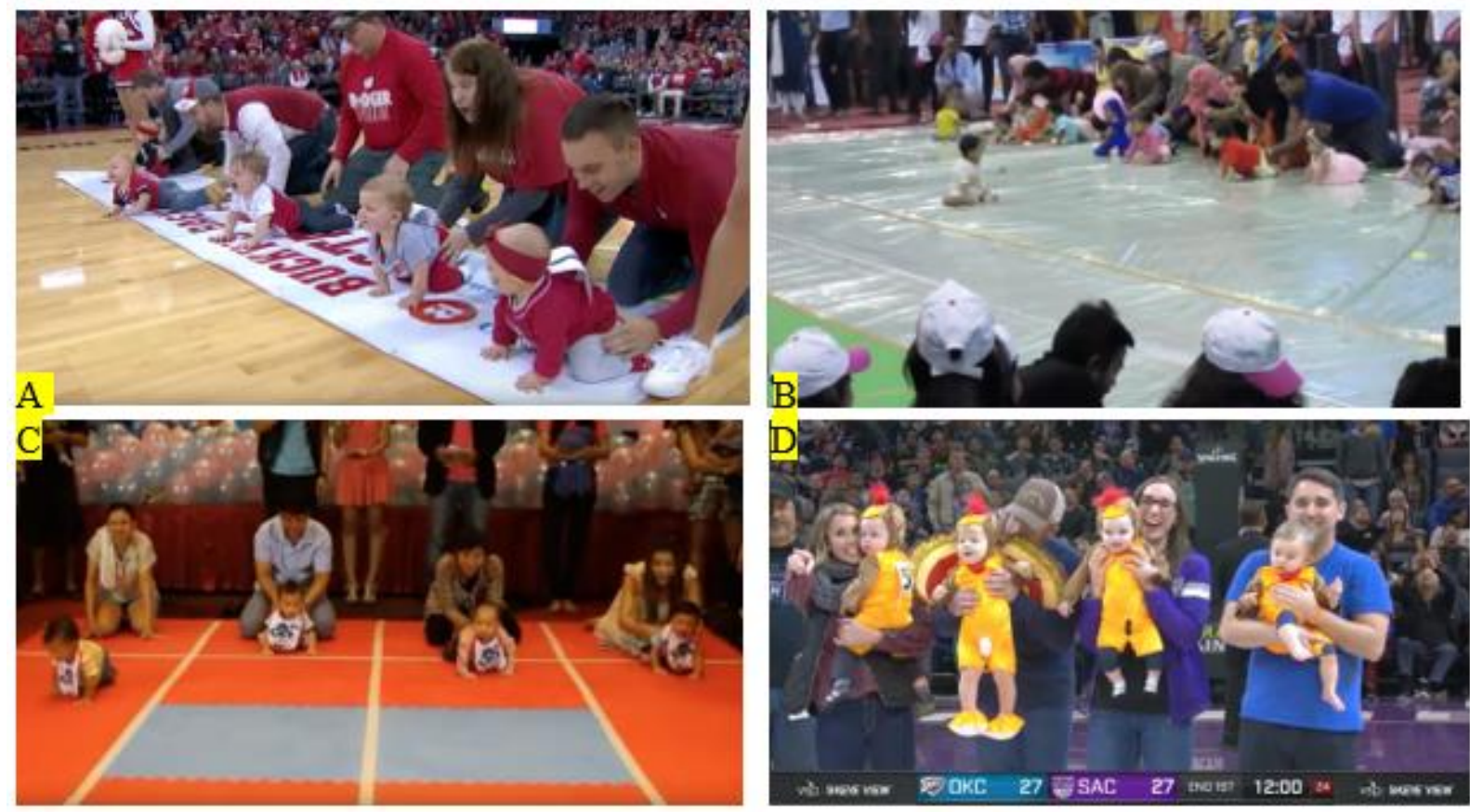

Sources: A-Wisconsin Badgers (Wisconsin Basketball Halftime Baby Race, YouTube); B-LearnThai2gether (Baby Olympics, Thailand, YouTube); C-Easy Learn Tips (Funny Baby Crawling Competition, YouTube); D-Sacramento Kings (Kaiser Permanente Thanksgiving Baby Race 2016, YouTube).

Figure 2. Pic Mosaic of video screenshot of other cases similar to the Baby Olympics outside GCC and MENA region.

The events which include participation from babies and toddlers have opened a new frontier in discussion for the early age participants in sporting events and the associated marketing techniques and campaigns leveraging the culture across the continents. The impact of IOC video is not related to sporting competitions 
but to understand and analyse the various marketing techniques deployed in relation to the culture. Observing the Figure $3 \mathrm{~A}$ is possible to see how the elite sports schools in the People's Republic of China (PRC) recruit student athletes as young as four years old and put them through regimented training routines in the hopes of creating an Olympian athlete (ITV News, 2016). Only ten percent of over half-a-million children training at these schools will secure an opportunity to represent the nation at the Olympics or compete for a National level berth. This creates a huge void in their lives if they are not able to realise their sporting dream as in the case of Mr Zhang Shangwu (Moore, 2011). He was recruited at the age of six and sold a dream of being a member of the Olympics gymnastics contingent, but an injury sustained at the age of eighteen forced him to resort to selling bracelets on a subway to make ends meet due to no formal education or vocational skills training. The Dengfeng county in the PRC houses a Shaolin school of Buddhism in which children as young as six years old are subjected to rigorous training with a goal to become the next Shaolin master. It is believed the employed training methods will help the children to build a strong character in the society (South China Morning Post, 2019). "They have been learning Kung Fu at the Shaolin temple for only a year. When they first came here, they looked like effeminate little kids, knowing nothing. After continuous exercise, they grew up to be little men with strong wills" - Yan Huan, master monk, Shaolin temple (see Figure 3 B).

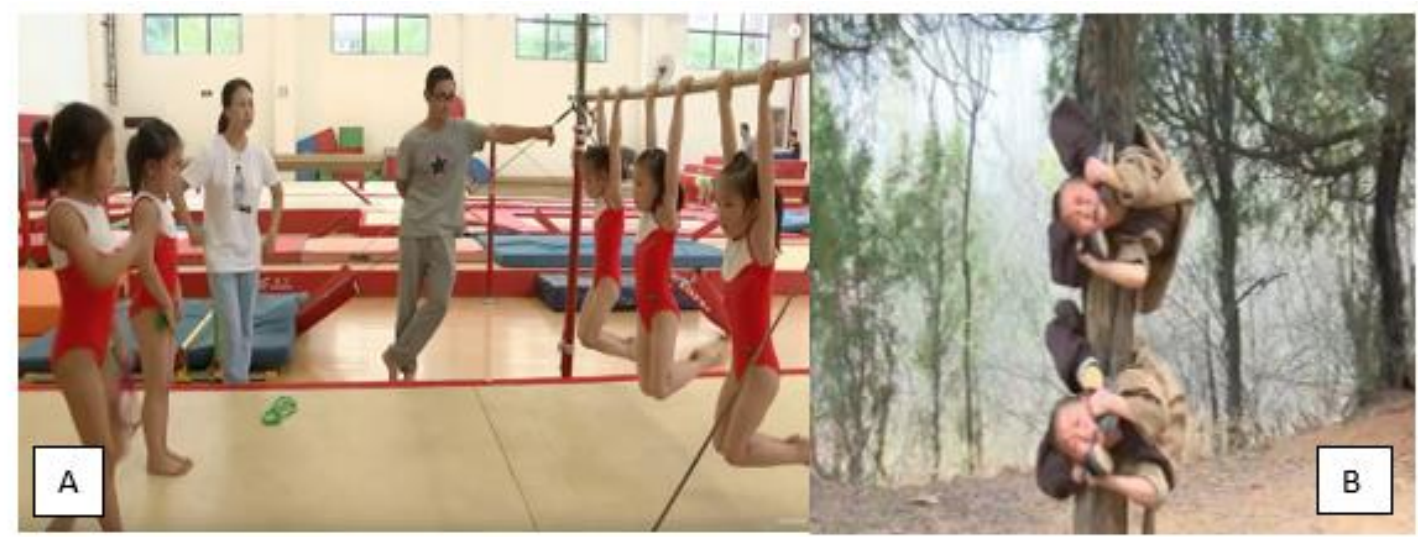

Source: A-ITV news (Inside China's gruelling sports schools, YouTube); B-South China Morning post (Young Chinese Shaolin monks display amazing feats of flexibility, YouTube).

Figure 3. (A) Young children in China as young as just 4 years old train for almost 10 hours daily, so that China can produce the next generations of Olympic champions. (B) Young children in China to become future Shaolin monks.

Hyman (2010) stated that doctors specialised in sports science are sceptical of the benefits gained by a baby through attending training sessions in exclusive facilities or watching content related to sports skills and drills such as a DVD of Baby Goes Pro to develop athletic talent. It could act as a burden for the babies, both emotionally and physically, and hamper their natural development (Huchison, 2011).

Sportswear for toddlers is priced on the higher side; a jogger set manufactured by Adidas and a national football team replica kit from Nike is priced at AED 199 (USD 54) and AED 279 (USD 76) respectively (Kids; Babies and Toddlers). The purchase of suitable garments for toddlers practising sports could burn a hole in the pocket of the parents.

Baerke Van der Meij, an 18-month old toddler, signed a 10 year professional contract with Dutch football club VVV Venlo while a 20-month baby, Bryce Brites, also signed a professional contract with FC Racing Boxberg (ESPN Sports Media, 2011; Sanderson, 2013). Monetary gains for the family from the professional contracts 
are confirmed but it could put the babies under extreme pressure to perform at the highest required level, in turn, affecting their development (Melina, 2011).

The lack of facilities for toddlers to practice sports, hone their skills and later represent the nation at international events could act as a stumbling block for the UAE in the achievement of National Agenda 2021 (UAE Vision 2021, 2018). In addition, a curriculum needs to be developed by expert coaches and trainers for toddlers keeping in mind the local culture and constraints such as harsh weather conditions.

The existence of a cultural barrier coupled with misconceptions prevents the parents from enrolling their toddlers in sports programs. The achievements of a toddler in the Baby Olympics could make him an overnight star and raise expectations, non-fulfilment of which could result in disappointment and have a negative psychological impact.

\section{CONCLUSION}

The participation of babies in the Baby Olympics could be viewed by activists as a violation of human rights and modern-day form of "child labour" because examples such as the ones present can be viewed as harsh and extensive training for children of such an age. However, the early integration of children into sport is not only an opportunity to create future star athletes, but also an opportunity to raise awareness on the misconceptions about child athletes. It could also be utilised to embed the values and principles of the Olympics into the children which can result in numerous benefits for the society as a whole; lead to the country's overall development and create a more active, energetic, and outgoing Arab society. The counties of MENA Region are sharing Olympic Values in the event and promoting Olympic Education according to their posts in the social media channels and official portals.

There are a lot of different perceptions about the Baby Olympics, whether it is a learning opportunity for the babies or a cruel manner of treating young innocent children. The most effective strategy is to include them in such types of Olympics so that they are well equipped to handle themselves physically and emotionally.

The Baby Olympics could also provide the young participants with a platform to exhibit their athletic talents; formal education and vocational skills training is also important if the athlete suffers a setback in his career or does not plan to pursue the sport further. We must make sure that it is in a fun setting for the babies and they are willing to perform it for them to have the best of both worlds and benefit their nation in distinguished aspects.

\section{REFERENCES}

Al Ahly TV. (2019, January) وزير الثب والرياضة يعلن عن أوليمبياد الطفل المصري [Minister of Youth and Sports announces the start of the Egyptian Baby Olympics] https://www.youtube.com/watch?v=4L6RnYVHKvM

AlArabiya. (2017, October). أطفال رضع في أول أولمبياد للطفل في جدة [Babies participate in the first Baby Olympics in Jeddah. https://www.youtube.com/watch?v=j|ZiLM4bASQ

Babies \& Toddlers Clothing (n.d.) https://store.nike.com/ae/en_gb/pw/babyclothing/1mdZbpa?sortOrder=finalpricelasc

Bahrain News Agency. (2019, April). 1,029 compete in Bahrain Baby Games. https://www.bna.bh/en/1029competeinBahrainBabyGames.aspx?cms=q8FmFJgiscL2fwlzON1\%2B Dn\%2BwRtUDvwlpa3e5T4Q5zcg\%3D 
Easy Learning Tips. (2017, March) Funny Baby Crawling Competition. https://www.youtube.com/watch?v=CPnQREOSXU0

ESPN Sports Media. (2011, April). Dutch side sign up toddler on ten-year deal http://en.espn.co.uk/football/sport/story/87791.html

General Authority for Entertainment. (2017). Baby Olympics Event 2017. https://roznamah.sa/en/events/baby-olympics-event-2017/

Hutchins, B., \& Mikosza, J. (2010). The Web 2.0 Olympics: Athlete blogging, social networking and policy contradictions at the 2008 Beijing Games. Convergence, 16(3), 279-297. https://doi.org/10.1177/1354856510367618

Hutchison C. (2011). Barely Walking Yet, but Kicking a Soccer Ball. https://abcnews.go.com/Health/Fitness/sports-tots-young-young/story?id=14181568

Hyman M. (2010). Sports Training Has Begun for Babies and Toddlers. https://www.nytimes.com/2010/12/01/sports/01babies.html

International Olympic Committee (IOC). (2015, December). The YOG - Vision, Birth and Principles. https://stillmed.olympic.org/Documents/Reference_documents_Factsheets/The_Youth_Olympic_G ames.pdf

ITV News. (2016, August). Inside China's gruelling sports schools https://www.youtube.com/watch?v=081 tuQSXbiw

Khaleej Times. (2004, June). Toddlers get set for Baby Olympics. https://www.khaleejtimes.com/nation/general/toddlers-get-set-for-baby-olympics

Kids. (n.d). Infants https://shop.adidas.ae/en/kids-infants?limit=120\&order=price-low-high

LearnThai2gether. $\quad(2017, \quad$ April). $\quad$ Baby $\quad$ Olympics. Thailand https://www.youtube.com/watch?v=s0r4PmUNX8k

MangoTango. (2016, August) Minecraft - Who's Your Mommy? - Baby Olympics! https://www.youtube.com/watch?v=N0EX24xp3xA

Marshall, P. D., Walker, B., \& Russo, N. (2010). Mediating the olympics. Convergence, 16(3), 263-278. https://doi.org/10.1177/1354856510367619

Mataruna L, Melo T, Guimaraes A, Petersen-Wagner R, Range D. (2015) Olympic Agenda 2020, Social Media and Online Strategies For The Social Value Of The Olympic Games. In: Deslandes A, Dacosta L, Miragaya A, editors. The Future of Sports Mega-events http://correrbem.org.br/wpcontent/uploads/2015/06/The-Future-of-Sports-Mega-events-new-book-on-Agenda-2020.2015_06_15.pdf

Mataruna-Dos-Santos, L. J., Khan, M. S., Ahmed, M. A. H. M. S., \& Al Shibini, A. (2018). Contemporary scenario of Muslim women and sport in the United Arab Emirates: Pathways to the vision 2021. Olimpianos-Journal of Olympic Studies, 2(2), 449-474. https://doi.org/10.30937/25266314.v2n2.id56

Mataruna-Dos-Santos, L.J., Zardini-Filho, C.E., \& Cazorla, A. (2019). Youth Olympic Games: Using marketing tools to analyse the reality of GCC countries beyond Agenda 2020. Journal of Human Sport and Exercise, 14(3proc), S391-S411. https://doi.org/10.14198/jhse.2019.14.Proc3.12

Melina R. (2011). Can a Toddler's Athletic Skills Foretell Success? https://www.livescience.com/33243toddlers-skills-foretell-future-athletic-performance.html

Moore M. (2011). Top Chinese gymnast found begging on the street. https://www.telegraph.co.uk/news/worldnews/asia/china/8645237/Top-Chinese-gymnast-foundbegging-on-the-street.html

Olympic Channel (2017, April). If Cute Babies Competed in the Olympic Games. https://www.youtube.com/watch?v=x04jgjQ_hLI 
Olympic Channel. (2018, February) If Cute Babies Competed in the Winter Games. https://www.youtube.com/watch?v=0pJU3jm0zkl

Pumerantz Z. (2012) Ranking the Biggest Events in Sports. https://bleacherreport.com/articles/1247928ranking-the-biggest-events-in-sports\#slide1

Sacramento Kings. (2016, November). Kaiser Permanente Thanksgiving Baby Race 2016 [video on the Internet]. https://www.youtube.com/watch?v=cX7mpzGJ6PI

Sanderson J. (2013) 20-month-old toddler becomes youngest professional footballer in the world. https://metro.co.uk/2013/11/30/20-month-old-child-becomes-youngest-professional-footballer-inthe-world-4208126/

Sopko C. (2018, February) How Social Media Has Changed the 2018 Winter Olympic Games for Marketers. $\quad$ https://www.adweek.com/digital/chandler-sopko-adaptly-guest-post-2018-winterolympic-games/

South China Morning Post. (2019, April). Young Chinese Shaolin monks display amazing feats of flexibility. https://www.youtube.com/watch?v=6pPu-gSf-Tg\&feature=emb_logo

Souza, A.L., Mataruna-Dos-Santos, L.J., and Tavares, O. (2019). The Youth Olympic Games, The Olympic City: Buenos Aires. In: Rubio, K. Sport and Olympic Movement in the 21st Century. São Paulo, Laços Ltda, ISBN 978858373 198-6.

The World Bank Group. (n.d). Middle East and North Africa. https://www.worldbank.org/en/region/mena UAE Vision 2021. (2018) Number of Olympic And Paralympic Medals Won. https://www.vision2021.ae/en/national-agenda-2021/list/card/number-of-olympic-and-paralympicmedals-won

Wisconsin Badgers. (2017, December) Wisconsin Basketball Halfime Baby Race. https://www.youtube.com/watch?v=zoZu3VIGev0

Wozniak K. (2019, December). STEEPLE Analysis. https://ceopedia.org/index.php/STEEPLE_analysis

\section{(C) $(1) \Theta$}

This work is licensed under a Attribution-NonCommercial-NoDerivatives 4.0 International (CC BY-NC-ND 4.0). 